\author{
OIKYA, Upal Aditya* \\ $\mathrm{PhD}$ Student \\ PTE ÁJK
}

DOI: 10.15170/DIKE.2020.04.02.08

\title{
Wartime Sexual Acts as Prosecutable War Crimes
}

Human history is littered with the mass rape of women particularly as a military strategy in warfare, dating back centuries from ancient Greek, Roman, and Hebrew concubines through the Middle Ages to the 20 $0^{\text {th }}$ century 'comfort women' of the $2^{\text {nd }} W$ orld War.' Ancient literature explicitly refers to rape or the seizure of vanquished women, who were regarded as the enemy's property, to become wives, servants slaves, or concubines. ${ }^{2}$ The plight of women worsened in the twentieth century when civilian women suffered the most consequences of armed conflicts including rape. ${ }^{3}$ Rape served as an oppressive and humiliating tool to severe family identity to dominate, demoralize, and destroy the entire enemy society and way of life. In the past, there appeared to be no international law that specifically dealt with rape in armed conflicts. This was caused by the ambivalent relationship between the law of armed conflict and gender-based crimes. Rape was overlooked as an unfortunate yet inevitable by-product of war. Both international bumanitarian and human rights laws did not initially recognize rape as a serious war crime and a fundamental breach of human rights. This deafening legal silence and gap are being addressed through an ongoing evolutionary process by criminalizing wartime predatory sexual acts as a war crime, crimes against humanity, and even genocide. However, with the developments of international law and its practice, for the first time in the history, mass rape and sexual enslavement in the time of war be regarded as 'crimes against bumanity' in a landmark ruling from the Yugoslav W ar crime tribunal in the Hague on 22 February 2001. But, even before that, some prior legal instruments for example the Lieber Code, promulgated during the American Civil W ar regarded [wartime] rape as war crime with capital punishment. Thus, this paper aims to analyze how the historical legal instruments have articulated the extend of criminality and culpability of wartime rapes and other sexual violence and their nexus with crimes of humanity, genocide, and war crimes within the corpus of international norms and criminal probibitions as well as the historical development of wartime sexual acts as prosecutable war crimes.

Keywords: international humanitarian law, wartime rape, sexual violence, international criminal law

\footnotetext{
* Upal Aditya Oikya is a PhD Fellow at Doctoral School of Law, University of Pecs. He pursued his LL.M (Maritime Law) from BSMR Maritime University, and LL.B (Hon's) from BRAC University. He has served International Crimes Tribunal, Bangladesh as Research Intern. This paper is an extended version of a conference article, presented by the author in the University of Belgrade, Serbia in 2020.

${ }^{1}$ ISLAM, National Trials of International Crimes in Bangladesh 171.

${ }^{2}$ ISLAM, National Trials of International Crimes in Bangladesh 171.

${ }^{3}$ Meron, Shakespeare's Henry the Fifth and the Law of War 29-30; Against Our Will, Men, Women and Rape 30-115.
} 


\section{Prelude}

In human history, mass rape could be found as a military strategy in warfare, dating back centuries from ancient Greek, Roman, and Hebrew concubines through the Middle Age to the $20^{\text {th }}$ century 'comfort women' of the $2^{\text {nd }}$ World War. ${ }^{4}$ Violent gendered crimes such as rape, gang rape, sexual captivity, sexual slavery, forced pregnancy \& war-babies, sexual assault, invasive body search, and other similar acts of sexual terrorism were committed as a systematic military strategy in warfare. ${ }^{5}$ In most of the time, the women are regarded as the enemy property, to become wives, servants slaves, or concubine. ${ }^{6}$

In ancient times, [by reading Homer's Iliad] we can see that the rape of women by warriors in warfare was a socially acceptable practice in ancient Greece. During the Middle ages, most of the jurists concluded that there were no limits in the way wars should be fought, thus atrocities committed against women and children were regarded as "part and parcel of the war". "While discussing the status of sexual atrocities from ancient times till the middle ages, Susan Brownmiller [1975] expressed that the women were not protected from abuses, neither in peacetime, nor in wartime. ${ }^{8}$ However, some jurists tried to systematized the laws of war during $15^{\text {th }}$ and $16^{\text {th }}$ century, but to the winning soldiers, women remained the available objectives. ${ }^{9}$ In $17^{\text {th }}$ century, Hugo Grotius proclaimed that rape "should not go unpunished in war any more than in peace". ${ }^{10}$ However, the opposite side of the coin was - these kinds of sexual enslavement and rapes are regarded as the 'deserved prize' for the conqueror to boost the morale of the army - it was the approach. Some examples could be Sudan, the Democratic Republic of Congo, Bosnia, Sierra Leone, Liberia, Chad, Rwanda, the former Yugoslavia - [where] rape was used a military tactic to achieve political and military objectives. ${ }^{11}$ Interestingly, history showed us that to avoid the rape of civilians, many attempts were taken, such as Japanese military authorities introducing military brothels, the so called "comfort-women system" after the widespread rape of civilians that occurred in Nanking. ${ }^{12}$ Even in Sierra Leone, the RUF force engaged in frequent rapes of civilians despite the fact that they detained many women as sex slaves. ${ }^{13}$ During WW2, the Nazis set up military brothels throughout much of occupied Europe. ${ }^{14}$ According to Manenti, "along with those in concentration camps' brothers, at least 34140 European women were forced into prostitution/sexual slavery during

\footnotetext{
${ }^{4}$ ISLAM, National Trials of International Crimes in Bangladesh 171.

${ }^{5}$ ISLAM, National Trials of International Crimes in Bangladesh 169.

${ }^{6}$ ISLAM, National Trials of International Crimes in Bangladesh 169.

${ }^{7}$ ASKIN, War Crimes Against Women, supra at 77, 24, citing by BrownMILLER, Against Our Will, Men, Women and Rape 31-113.

8 ASKIN, War Crimes Against Women, supra at 77, 24.

${ }_{9}$ ASKIN, War Crimes Against Women, supra at 77, 24.

10 Grotius, De Iure Belli ac Pacis Libri Tres 656-657. The publication of De Iure Belli ac Pacis by Hugo Grotius in 1625 had marked the emergence of international law as an autonomous legal science.

11 MANENTI, Wartime Sexual Violence as an International Crime 19.

12 WoOD, Armed Groups and Sexual Violence 14.

13 WOOD, Armed Groups and Sexual Violence 24.

14 WoOD, Armed Groups and Sexual Violence 25.
} 
the German occupation". ${ }^{15}$ Manenti also mentions that mass rape was committed by Goumiers [French Moroccan Troops] in Italy after the Battle of Monte Cassino. ${ }^{16}$ In the Bosnian war, 20.000-50.000 Bosnian Muslim women were raped by Bosnian Serb soldiers in a systematic campaign of humiliation and psychological terror. ${ }^{17}$ In Kosovo war, 20000 women were abused by Serbian and Yugoslav forces, in Bangladesh, 01 million women were sexually assaulted, in Rwanda, 250.000-500.000 women were abused as estimated, in Sierra Leone, 60.000 women were raped, in Liberia, between 60\% to 90\% of all Liberian women were raped during the conflict. ${ }^{18}$

The way these acts happened cast doubt on considering them as war crimes/genocide/crimes against humanity, because in a way they look very random or byproduct of war, however these were indeed very systematic, and part of conscious and deliberate policy of the oppressive group. As mentioned by Islam, these policies are designed to be the ultimate victory, the conquest of the very essence of the entire community. In the post-second world war era, the world expected to protect human rights and dignity even if in the warfare, however there are ample of examples where in the national and/or international conflicts, this cherished aspiration was not found, such as in the Bangladesh Liberation War, 1971. Despite the cherished aspiration of post-second world war, to protect human rights and dignity of all, the international community, the United Nations, international human rights and international humanitarian law failed to safeguard the human rights and dignity of Bengali women and girls, who endure gruesome sexual crimes and violence from late March to midDecember $1971 .{ }^{19}$ As it is true that the international community failed to protect the basic human rights in most of the warfare, but in the same way it is also true that many jurists and scholars tried to make a model through which these kinds of atrocities could be minimized and finally in this modern era, the international community successfully buildup mechanisms where the sexual atrocities is not only prohibited in wartime, but in peacetime also. Thus this paper aims to trace the historical development of wartime sexual acts as prosecutable war crimes, and then to analyze how the International Crimes Tribunals/Courts articulated the extent of criminality and culpability of wartime rapes and other sexual violence and their nexus with crimes against humanity, genocide, and war crimes, within the corpus of international norms and criminal prohibitions.

\section{Wartime rape and sexual violence in International Humanitarian Law (IHL)}

In the past, there appeared to be no international law that specifically dealt with rape in armed conflicts due to the ambivalent relationship between the law of armed conflict and gender-based crimes. Often rapes and other sexual violence were overlooked as an unfortunate and opportunistic act, yet inevitable by-product of war.

\footnotetext{
15 WoOD, Armed Groups and Sexual Violence 25; Herbermann, The Blessed Abyss.

${ }^{16}$ Herbermann, The Blessed Abyss.

${ }^{17}$ Herbermann, The Blessed Abyss.; Gendercide watch, Case Study: Bosnia-Herzegovina.

18 WOOD, Armed Groups and Sexual Violence 29.

19 WoOD, Armed Groups and Sexual Violence 170.
} 
However, the Lieber Code promulgated during the American civil war for the first time regarded rape as a war crime with capital punishment. ${ }^{20}$ This Code marked the beginning of international attempts to single out rape and sexual violence as war crimes in codifying the rules of war. Subsequent international conventions enacted provisions for the humanitarian treatment of the civilians in armed conflicts providing explicit and implicit protection against wartime rapes and sexual violence. ${ }^{21}$

\subsection{The Hague convention}

The Hague Convention 1907 covertly prohibits rape by stating that "family honour and rights, the lives of person ... must be protected" [article 46]. The 'family honour' and 'right' encompassed the right of women to be protected from rape, forced prostitution, and other sexual violence. ${ }^{22}$ This convention regarded sexual abuses as an undignified act for the 'family honour' that violates 'family right', rather than an invasive act against the will and body of women. The protection of the right and dignity of women, the ultimate victims with physical pain psychological trauma and emotional distress, was only a secondary consideration subservient to the 'family honour'. ${ }^{23}$ Nonetheless, the Nuremberg Tribunal held that by 1939, the Hague Convention was widely recognized as the laws and customs of war codifying bilateral war treaties including the Lieber Code outlawing wartime rape and sexual abuse. ${ }^{24}$

The commission of rape during the Bangladesh Liberation War, 1971 was obviously humiliating for the victims' families in the society and infringed those families honour, dignity, and right. In their bid to escape from social stigma, ostracism, and indignity, many rape victims opted for abortions or abandoned their new-born war babies, while other migrated to India and/or committed suicide after being rejected by their families and societies. ${ }^{25}$

The law and customs of war as codified in the Hague Convention until 1939 prohibited wartime rape and sexual violence as war crimes. This Convention has been superseded by other laws and customs of war, but its pioneering symbolic value engineered subsequent conventions to combat wartime rape. ${ }^{26}$

\footnotetext{
20 The Lieber Code was issued on April 24, 1893 under General Order No. 100 by President Abraham Lincoln ordering the Union Forces of the US to follow certain specific rules of warfare in the field; Rhonda Copelon, General Crimes as War Crimes: Integrating Crimes against Women into International Criminal Law, McGill Law Journal 46, no. 1 (2000): 220.

${ }^{21}$ IsLAM, National Trials of International Crimes in Bangladesh 172.

22 ISLAM, National Trials of International Crimes in Bangladesh 172.

23 ISLAM, National Trials of International Crimes in Bangladesh 173.

24 ISLAM, National Trials of International Crimes in Bangladesh 172; The Nuremberg Judgment 248-249; MENON, Rape as a Crime 424; PARKER - CHEW, Compensation for Japan's World War II Victim 514.

25 MoOKherjeE, Mass Rape and the Inscription of Gendered and Racial Discrimination 67-78; SAIKIA, Beyond the Archive of Silence 275-287.

26 IsLAM, National Trials of International Crimes in Bangladesh 173.
} 


\section{DÍKÉ

\subsection{The Genocide Convention}

The Genocide Convention 1948 defines the crime of genocide as 'acts committed with intent to destroy, in whole or in part, a national, ethnical, racial or religious group'. Some of such acts are: (a) 'Cc]ausing serious bodily or mental harm to members of the group', (b) 'Cd] eliberately inflicting on the group conditions of life calculated to bring about its physical destruction in whole or in part', and (c) 'i i]mposing measures intended to prevent births within the group' (Article II).

Mass rapes in armed conflicts are usually committed against a national, ethnic, racial, or religious group. In the Bosnian armed conflict, the Serbian army committed indiscriminate rapes predominantly against Muslim women. ${ }^{27}$ During the Rwandan armed conflict, the Hutu militia raped the Tutsi women en mass. ${ }^{28}$ In the aftermath of the invasion of Iraq in 2003, there were instances of the rape of Iraqi women and girls, particularly by US troops. ${ }^{29}$ These instances of mass rapes fit the constituent elements of genocide as they were committed to cause serious physical injury and mental harm to the victims of a religious (Bosnian Muslim women), a racial or ethnic (Rwandan Tutsi women), and a national (Iraqi women and girls) group. ${ }^{30}$ Since these rapes were calculated to prevent births and/or dilute racial identity within the targeted groups and to destroy their culture and society, they constituted genocide, without any doubt. ${ }^{31}$

According to Islam, the systematic rape in armed conflicts as a constituent element of genocide in certain circumstances received the tacit judicial endorsement by the International Court of Justice (ICJ). ${ }^{32}$ In the application filed against Yugoslavia with the ICJ on March 20, 1993, BosniaHerzegovina alleged that the indiscriminate rape of Muslim women during the Bosnian conflict violated the Genocide Convention. ${ }^{33}$ Upon scrutiny of the allegations, the ICJ implicitly endorsed the existence of a nexus between genocide and rape in its provisional ruling in $1993 .{ }^{34}$ A direct casual link between genocide and systematic rapes was found by the ICTR: “... in societies where the membership of a group is determined by the identity of the father, rapes where the victim is made pregnant with the intention that she gives birth to a child who will not then belong to the mother's group are measures intended to prevent births within the group, thus genocide..." 35 The victims of rape are women, who as such do not constitute an exclusive group for the purpose of protection under the Genocide Convention, which does not specifically stress that

\footnotetext{
${ }^{27}$ The European Community investigative mission into the treatment of Muslim women in the former Yugoslavia: Report to EC Foreign Ministers, UN Doc. S/25240, Annex I; Niarchos, Women, War and Rape 649-651; RAY, The Shame of It: Gender-based Terrorism 793.

28 Report on the Situation of Human Rights in Rwanda to the Commission on Human Rights, UN Docs. E/CN.4/1996/68, 1996, para. 16; Final Report of the Commission of Experts on Rwanda, UN Doc. S/1994/1405 (1994), Annex.

${ }^{29}$ Photographs of sexualized abuses in the Abu Ghraib prison and around Iraq are well documented and publicized: FISHER, Iraqi Tells of US Abuse 8; Hersh, Torture at Abu Ghraib 42-44; GrEenBERG - Dratel, The Torture Papers 987.

${ }^{30}$ WOOD, Armed Groups and Sexual Violence 174.

31 WoOD, Armed Groups and Sexual Violence 174.

32 WOOD, Armed Groups and Sexual Violence 174.

33 WoOD, Armed Groups and Sexual Violence 174.

34 WoOD, Armed Groups and Sexual Violence 174; Applicatioin of the Convention on the Prevention and Punishment of the Crime of Genocide 24.

35 Prosecutor v Jean-Paul Akayesu, ICTR-96-4-T, Trial Judgment of September 2, 1998, para 597-598.
} 
women are to be protected from rape. ${ }^{36}$ This non-recognition of women as a distinct group may lead to a reluctance to classify wartime rape as genocide and to prosecute rape under the Genocide Convention. ${ }^{37}$ Firstly, the inalienable and primary identity of the rape victims is women, and they are rapped because they are women, who are also a members of a national, ethnic, racial, or religious group. ${ }^{38}$ The inextricable relationship between the gender and the crime warrants the recognition of women as a group to be protected as a focused goal, not an incidental one, under the Genocide Convention. ${ }^{39}$ This interpretive approach is crucial for IHL to be able to effectively combat genderrelated crimes in armed conflicts and restore the human rights of rape victims and their dignified existence in the society. ${ }^{40}$

\subsection{The Geneva Conventions and Additional Protocols}

According to Prof. Islam, if we read carefully, the Article 3 common to all four Geneva Conventions 1949 may be interpreted to cover the prohibition of rape in armed conflicts not of an international character. ${ }^{41}$ The Article does not mention rape explicitly but forbids violence to life and persons ... cruel treatment and torture' and 'outrages upon personal dignity, in particular humiliating and degrading treatment' against personals taking no active part in hostilities. Rape is a violent and torturous act that severs the personal dignity of victims in a humiliating and contemptuous manner. Thus, the text of Common Article 3 may be extrapolated to cover rape in cases of violence to life and person, and cruel and humiliating treatment to the personal dignity of rape victims. ${ }^{42}$

The coverage of rape has been specified and reinforced in the Fourth Geneva Convention on the Protection of Civilian Persons in Time of War. ${ }^{43}$ According to Article 27, it states that 'women shall be especially protected against any attack on their honor, in particular against rape, enforced prostitution, or any form of indecent assault'. This provision can be a viable tool for the prosecution of wartime rape because of its gender specific content. ${ }^{44}$ As mentioned by Prof. Islam, this Convention may also be used to protect women against sexual violence during armed conflicts as well. Even though it does not mention rape as a 'grave breach' of humanity, its listed examples include 'torture and inbuman treatment' and 'willfully causing great suffering or serious injury to body or health' [Article 147]. ${ }^{45}$ Thus with careful reading, it is understandable that the broad expression of the Article seems to inclusively include all manners of sexual violence. ${ }^{46}$ There can be hardly can doubt that rape is inhuman and cases

36 WoOD, Armed Groups and Sexual Violence 174.

${ }^{37}$ WOOD, Armed Groups and Sexual Violence 174.

38 WoOD, Armed Groups and Sexual Violence 174.

${ }^{39}$ WOOD, Armed Groups and Sexual Violence 174.

${ }^{40}$ WoOD, Armed Groups and Sexual Violence 175.

${ }^{41}$ WoOD, Armed Groups and Sexual Violence 175.

42 WoOD, Armed Groups and Sexual Violence 175.

${ }^{43}$ WOOD, Armed Groups and Sexual Violence 175.

44 WoOD, Armed Groups and Sexual Violence 175.

45 WoOD, Armed Groups and Sexual Violence 175.

46 WoOD, Armed Groups and Sexual Violence 175. 
great suffering or serious bodily and mental injury to the victims. ${ }^{47}$ The International Committee of the Red Cross (ICRC) has already endorsed this interface between rape and sexual violence and the state of physical health and enduring mental shock of the victims. ${ }^{48}$ The UN General Assembly Declaration on the Protection of Women and Children in Emergency and Armed Conflict 1974 reiterated protection against sexual violence much along the lines of the General Conventions without specifically rape, which can be established through extrapolation ad inference. ${ }^{49}$

Both Additional Protocols to the Geneva Convention from 1977 recognize and reinforce rape as a war crime. Protocol I expressly provides that 'women shall be the object of special respect and shall be protected in particular against rape, forced prostitution and any other form of indecent assault' in international armed conflicts [Article 76.1]. Rape is also outlawed by Protocol II pertaining to noninternational armed conflicts [Article 2(e)].

\section{Wartime Rape and Sexual Violence in International Criminal Law}

\subsection{The Nuremberg and Tokyo Tribunals}

The war crimes tribunals that tried Nazi and Japanese atrocities of the Second World War were founded on the traditional notion of the power of the victor states over the defeated states after the surrender of the Nazi and Japanese Imperial armies. The Charter of both the Nuremberg Tribunal and the Tokyo Tribunal focused only on serious crimes under the established norms of war crimes and contrary to public conscience. ${ }^{50}$ Their mandates did not include gender-based crimes despite the existence of extensive evidence of systematic rape and forced prostitution, exemplified by the 'comfort women' stations set up by the Japanese Imperial Army. ${ }^{51}$

The Tokyo Military Tribunal discussed the issue of rape but held that rape fell short of being a 'serious crime' in its mandate and that such non-serious crimes committed by Japanese troops would be charged and tried separately. ${ }^{52}$

Thus, these two historic trials somewhat reiterated the status quo of rape as a by-product of war and the ambivalent position of international law on wartime sexual violence. As consequence, the perpetrators of mass rapes during the Second World War were not punished or called to account for their criminal acts. ${ }^{53}$

${ }^{47}$ WoOD, Armed Groups and Sexual Violence 175.

48 WOOD, Armed Groups and Sexual Violence 174; ICRC Update on the Aide-memoire, December 3, 1992; DURHAM GURD, Listening to the Silences 25-31.

${ }^{49}$ DurHAM - GuRD, Listening to the Silences 25-31; GA Res. 3318, UN Doc. A/9631, 1974.

${ }^{50}$ WOOD, Armed Groups and Sexual Violence 176.

51 WooD, Armed Groups and Sexual Violence 176; Report on the Mission to the Democratic People’s Republic of Korea, the Republic of Korea and Japan on the Issue of Military Sexual Slavery in Wartime For analysis on 'comfort women' see HiCKs, Ghosts Gathering 32-36; Boling, Mass Rape, Enforced Prostitution, and the Japanese Imperial Army 551; YU, Reparations for Former Comfort Women 531-532.

52 COPElOn, Note 4, 197; MCCORMACK, Selective Reaction to Atrocity 718-719.

53 WoOD, Armed Groups and Sexual Violence 177. 
As rightly mentioned by Prof. Islam, these horrendous armed conflicts, marked by unimaginable sexual brutality perpetrated against innumerable women in genocidal and ethnic cleansing conditions. ${ }^{54}$ However, international reluctance to act led to the creation and networking of a coalition of global human rights NGOs, feminist movements, and technology based mass and social media outlets to launch a consciousness-raising campaign for corrective justice to the rape victims and ending the impunity of their perpetrators. ${ }^{55}$ This powerful lobby forced a reaction from the international community to confront the disturbing history of impunity for wartime rape by recognizing it as a serious crime and fundamental breach of human rights. ${ }^{56}$ This development has been reflected in the ICC Statutes, which have criminalized rape as a crime against humanity in times of war and peace. ${ }^{57}$

\subsection{The ICC Statute}

The Rome Statute of the International Criminal Court, 1998 represents an advancement in the international jurisprudence of gender-based crimes. According to ICC - Article 7 (1) (g), Rape is one of its enumerated acts constituting crime against humanity in the broadest possible sense that inclusively includes rape, sexual slavery, enforced prostitution forced pregnancy, enforced sterilization, or any other form of sexual violence of a comparable gravity. As per ICC - Article 7 (2)(c), forced enslavement is a form of sexual violence because it involves 'the exercise of any or all of the powers attaching to the right of ownership over a person and includes the exercise of such power in course of trafficking in persons, in particular women and children'. As per ICC-Article 7(2)(f), forced pregnancy can be a means of committing genocide as it involves the unlawful confinement of a women forcibly made pregnant with the intend of affecting the ethnic composition of a population. In addition to the political, racial, or religious persecutory grounds prescribed in the Nuremberg Charter [Article 6(c)] and the Statutes of ICTY [Article 5(h)] and ICTR [Article 3(h)], the ICC Statute has added national, ethnic, cultural, and gender grounds [Article 7(1)(h)]. ${ }^{58}$ These progressive developments advance the cause of justice to the women victims of rape and sexual violence drawing no distinction between their commission in wartime and peacetime. ${ }^{59}$

As mentioned by Prof. Islam, the ICC responses to the charge of rape and sexual violence as weapons of war in armed conflicts has been gradual as evidenced in its judgments in three successive cases on the Situation in the Democratic Republic of the Congo (DRC) and the Central African Republic (CAR). In the Katanga case, the ICC Trial Chamber II found Germain Katanga guilty of crime against humanity and war crimes for committing only murder and pillaging, but not for rapes and sexual slavery included in the charges. ${ }^{60}$ Katanga was one of the commanders present in Bogoro

\footnotetext{
54 WoOD, Armed Groups and Sexual Violence 177.

55 WoOD, Armed Groups and Sexual Violence 177.

56 WoOD, Armed Groups and Sexual Violence 177.

${ }_{57}$ WoOD, Armed Groups and Sexual Violence 177.

${ }^{58}$ WOOD, Armed Groups and Sexual Violence 178.

59 WoOD, Armed Groups and Sexual Violence 178

${ }^{60}$ Prosecutorv Germain Katanga, ICC-01/04-01/07, trial judgment of March 7, 2014, and sentenced to 12 years imprisonment on May 23, 2014, but the Appeals Chamber reduced the sentence on review on November 13, 2015.
} 
massacre in Democratic Republic of Congo (DRC), which experienced a high level sexual violence, rapes, sex slaves, and forced marriage of women and girls. ${ }^{61}$ A conviction for sexual crimes would have been a milestone in the future dealing of similar charged in national and international courts/tribunals and in sending a message across that no impunity exists for sex crimes. ${ }^{62}$ In Gombo case, the ICC Trial Chamber III unanimously convicted the former Congolese Vice President JeanPierre Bemba for rapes committed between October 2001 and March 2003 as crime against humanity under Article 7 (1)(g) and war crimes under Article 8(2)(e)(vi). ${ }^{63}$

In Ntaganda case, the ICC Trial Chamber VI has been very innovative and expansive in the interpretation of rape crimes in armed conflicts. ${ }^{64}$ It convicted Bosco Ntaganda for rape and sexual slavery of the civilians and combatants, including the rape victims of combatants from the same side of armed forces as the perpetrators. ${ }^{65}$ It argued that the prohibition of rape has jus cogens status in international law and that it was applicable at all-time, in peace and armed conflicts alike, and against all persons irrespective of their status as the civilians, enemy combatants, or same side combatants. ${ }^{66}$ The prohibition of rape and sexual violence is not restricted to certain groups of protected persons; rather anyone regardless of status can be a victim of war crimes. ${ }^{67}$ This interpretation of wartime rape committed as a weapon of war provides the highest level of protection to the victims of wartime rape and is consistent with the International Red Cross commentary to Common Article 3 of the Geneva Conventions, requiring 'all parties to the conflict should, as a minimum, grant humane treatment to their own armed forced based on Common Article 3,.68

The ICC jurisdiction, being contractual in nature exercisable over the individuals of ICC-member states, falls short of affording a true universal jurisdiction. ${ }^{69}$ The limitation is serious as most armed conflicts are internal in nature and crimes committed during such conflicts are likely to remain beyond the reach of the ICC. ${ }^{70}$ Many states including some powerful states, are yet to be the ICC members and they may commit serious wartime atrocity crimes of rape and sexual violence with impunity. For example, US troops in Iraq responsible for sexual violence, rape and torture has a sexualized component and both were used to dehumanize the Iraqis. ${ }^{71}$ Similarly, soldiers of any other non-party state can commit the ICC designated crimes of rape and sexual violence without any concern for ICC jurisdiction. $^{72}$

${ }^{61}$ WoOD, Armed Groups and Sexual Violence 178.

62 WoOD, Armed Groups and Sexual Violence 178.

${ }_{63}$ Prosecutor v Jean-Pierre bembe Gombo, ICC-01/05-01/08, trial judgment of March 21, 2016 and sentenced to 18 years imprisonment on June 21, 2016.

${ }^{64}$ WOOD, Armed Groups and Sexual Violence 179.

65 WoOD, Armed Groups and Sexual Violence 179.

66 Prosecutor v Bosco Ntaganda, ICC-01/04-02/06, trial judgment of January 4, 2017, para 47, 51-53.

${ }^{67}$ WoOD, Armed Groups and Sexual Violence 178.

68 The Applicability of Common Article 3 to all civilians and to a Party's own armed forces, Contents E, sub-para (1): Persons Protected, para 549.

${ }^{69}$ WoOD, Armed Groups and Sexual Violence 178.

70 WoOD, Armed Groups and Sexual Violence 178.

${ }^{71}$ WoOD, Armed Groups and Sexual Violence 178.

72 WoOD, Armed Groups and Sexual Violence 178. 


\section{Wartime Rape and Sexual Violence in Special International Crimes Tribunals/Courts}

It is quite noteworthy to state that the development of the prosecution of rape or any sexual violence in armed conflicts and its impacts on shaping the contemporary International Humanitarian Law (IHL) and International Criminal Law (ICL) has been gradual, but focused. ${ }^{73}$ The international community and United Nations (UN) have been establishing various ad hoc international crimes tribunals and courts to respond to the perpetration of massive violence of IHL in armed conflicts. ${ }^{74}$ Most importantly the response of these tribunals/courts, adopted rules and principles of evidence taking in sexual assault cases are remarkable. ${ }^{75}$

\subsection{International Criminal Tribunal for the former Yugoslavia (ICTY)}

The Tadic $\operatorname{case}^{76}$ was the first ever ICTY trial of rape and gendered violence, where Tadic was tried and convicted in May 1997 for sex crimes, inter alia, and received a 20-year sentence. ${ }^{77}$ As mentioned by Prof. Islam, in this case, the ICTY opinions can have significant ramifications for the future trials of gender-based crimes. Of several charged, Count 1 of the indictment charged Tadic with crime against humanity - a crime that included rape and other forms of sexual violence. ${ }^{78}$ Another notable issue is that Tadic was convicted for sex crimes even though it could not be proved that he himself committed sexual violence. ${ }^{79}$ According to the judgment, he was held responsible for his participation in aiding and abetting a campaign of terror, manifested by murder, rape, torture, and other forms of violence. ${ }^{80}$ The honorable Tribunal relied on the criminal law principle of personal culpability for assisting, aiding, and abetting to establish that non-physical perpetrators can be responsible for sexual violence. ${ }^{81}$

Hence, individuals who do not take part in rape but encourage or help others, overtly or covertly, to commit rape may be held accountable. ${ }^{82}$ As mentioned by Patricia Sellers, any individual could be convicted with evidence implicating him personally in rape, provided his individual criminal responsibility emanates from aiding and abetting the commission of the crimes, even if he is from low-level participants. ${ }^{83}$

\footnotetext{
73 IsLAM, National Trials of International Crimes in Bangladesh 180.

74 IsLAM, National Trials of International Crimes in Bangladesh 180.

75 IsLAM, National Trials of International Crimes in Bangladesh 180.

${ }^{76}$ Prosecutor v Dusko Tadic, IT-94-1-T, Trial Judgment of May 7, 1997.

77 WoOD, Armed Groups and Sexual Violence 181.

${ }^{78}$ WoOD, Armed Groups and Sexual Violence 181.

${ }^{79}$ WoOD, Armed Groups and Sexual Violence, para 2.

80 Prosecutor v Dusko Tadic, IT-94-1-T, Trial Judgment of May 7, 1997, para 27, 151, 154, 165, 175, 194-98, 206, 227, 228, 237, 470, 718, 726, 730 .

81 Prosecutor v Bosco Ntaganda, ICC-01/04-02/06, trial judgment of January 4, 2017, para 47, 51-53.

82 Prosecutor $v$ Bosco Ntaganda, ICC-01/04-02/06, trial judgment of January 4, 2017, para 47, 51-53.

83 SELLERS, Individual('s) Liability for Collective Sexual Violence 153-94; SELLERS - OKIZUMI, International Prosecution of Sexual Violence 1.
} 
The Furundrija case ${ }^{84}$ focused on the commission of indirect sexual violence. ${ }^{85}$ As mentioned by Prof. Islam, the allegatioins were based on Furundzija's presence or authority when sexual violence was committed, thus the charge was that he did nothing to stop the rape alleged and that his acts or omissions implicitly encouraged or endorsed sexual violence, which amounted to assisting, aiding, and abetting. Notably, the honorable Tribunal expanded the definition of rape by including both oral and anal penetration and held that, apart from rape, other lesser forms of sexual assault were covered by the expression 'other inhumane acts' in the ICTY Statute - Article 5(i).$^{86}$

Moreover, remarkably in the case of Prosecutor $v$ Radislav Krstic ${ }^{87}$, the judicial inference received a further boost that established a link between rape and ethnic cleansing constituting crimes against humanity. Because the trial chamber found that the rape victims were 'selected only because of their membership of a group' contemplated to destroy 'specifically the Bosnian Muslim group as the ultimate step' and that the accused committed these crimes deliberately evidencing the genocidal intent to destroy the family structure and reproduction of a national religious group. ${ }^{88}$

In the case of Prosecutor $v$ Slobodan Miljkovic et al., the ICTY significantly continued to break the new jurisprudential grounds on the charges of rape and sexual violence. ${ }^{89}$ In the above mentioned case, the accused were charged with crime against humanity who forced two male prisoners in the Bosanki Samac camp to perform sexual acts on each other. ${ }^{90}$ For the first time in history, it was recognized that men can also be raped constituting a serious crime in international law is a fundamental new development. ${ }^{91}$

\subsection{International Criminal Tribunal for Rwanda (ICTR)}

The ICTR defined rape and sexual violence broadly. ${ }^{92}$ It went beyond 'non-consensual sexual intercourse' by including 'acts which involve the insertion of objects and/or the use of bodily orifices not considered to be intrinsically sexual, such as thrusting a piece of wood into the sexual organs of a women as she lay dying constitutes rape. ${ }^{93}$ The form of coercion includes not only physical force, but threats, intimidation, extortion, and other duress that prey on fear or desperation. ${ }^{94}$ Thus, the existence of armed conflict, military personnel, and the militia was found to be inherently coercive and forced nudity even without touching was a form of coercive and inhumane sexual violence, constituting crime against humanity. ${ }^{95}$

\footnotetext{
${ }^{84}$ Prosecutor v Anto Furundzija, IT-95-17/1-Y, Trial Judgment of December 10, 1998.

85 WoOD, Armed Groups and Sexual Violence 182.

86 WoOD, Armed Groups and Sexual Violence 182.

87 Prosecutor $v$ Radislav Krstic, IT-98-33-T, Trial Judgment of August 2, 2001, para 3-5, 46, 150, 517, 616-618, 653, 687-688

and IT-98-33-A, appeal judgment of April 19, 2004, concurring with the trial findings.

${ }^{88}$ IsLAM, National Trials of International Crimes in Bangladesh 183.

${ }^{89}$ ISLAM, National Trials of International Crimes in Bangladesh 184.

${ }^{90}$ Prosecutor $v$ Slobodan Miljkovic et al., IT-95-9, indictment order of July 21, 1995.

91 WoOD, Armed Groups and Sexual Violence 78.

92 WoOD, Armed Groups and Sexual Violence 187.

93 WoOD, Armed Groups and Sexual Violence 187; Akayesu Case, note 11, para 686.

${ }^{94}$ Akayesu Case, note 11, para 686.

95 Akayesu Case, note 11, para 687- 688.
} 
Moreover, in the case of Musema $^{96}$, the ICTR trial chamber took an accompanied utterance of Alfred Musema while raping a Tutsi women - 'the pride of the Tutsis will end today' in the context to conclude that 'the acts of rape and sexual violence were an integral part of the plan conceived to destroy the Tutsi group', which was also upheld by the Appeal Chamber. ${ }^{97}$

Thus, these judgments have further consolidated the jurisprudence on rape and other sexual violence as part of genocide and crime against humanity.

\subsection{Special Court Sierra Leone (SCSL)}

The criminal jurisprudence pertaining to rape as a war crime progressed and redefined further in SCSL judgments. The civil war between government troops and Revolutionary United Front (RUF) continued over a decade. ${ }^{98}$ Both sides perpetrated, among other crimes, brutal sexual violence ravaged by villages targeting women and virgin girls and disempowering them. ${ }^{99}$ As mentioned by Louise Taylor, nearly 250 thousand women and girls suffered sexual violence, including gang rape, sexual slaves, and murdered by violent rape. ${ }^{100}$

The SCSL Chief Prosecutor laid down specific charges of sexual violence in the very first indictments issued on March 7, $2003 .{ }^{101}$ In the case of Brima ${ }^{102}$ and Sesay ${ }^{103}$, the honorable court dealth with the prosecution of rape as a war crime on its own right and independently, as its Statute criminalized rape in armed conflicts as a chargeable offence all by itself, not just a catalyst or instrument of effecting genocide and/or ethnic cleansing. ${ }^{104}$ Moreover, apart from rape as a war crime, forced marriages, and other inhumane sexual acts were held to be war crimes covered by 'other inhumane acts'. $^{105}$

Thus, this judicial recognition of wartime rape alone as a chargeable war crime has taken the advancement of international criminal law of sexual violence to a new height. ${ }^{106}$

\footnotetext{
96 Prosecutor v Alfred Musema, ICTR-96-13-T, trial judgment and sentence of January 27.

${ }_{97}$ Prosecutor v Alfred Musema, ICTR-96-13-T, trial judgment and sentence of January 27, 200, para 933, 797-862; ICTR-9613-A, appeal judgment of November 16, 2001, para 64, 165-72, 194, 371; Prosecutor v Anto Furundzija, IT-95-17/1-Y, Trial Judgment of December 10, 1998, 188.

98 Prosecutor v Anto Furundrija, IT-95-17/1-Y, Trial Judgment of December 10, 1998,190.

${ }_{99}$ Prosecutor $v$ Anto Furundrija, IT-95-17/1-Y, Trial Judgment of December 10, 1998,190.

100 TAYLOR, 'We'll Kill You if You Cry' 10-25; FrITZ - SMITH, Current Apathy for Coming Anarchy 397.

101 ISLAM, National Trials of International Crimes in Bangladesh 190; BBC News Online, Surprise at Sierra Leone Arrests.

102 Prosecutor $v$ Tamba Brima et al., SCSL-04-16-T, trial judgment of June 20, 2007.

103 Prosecutor v Issa Hassan Sesay et al., SCSL -04-15-T, trial judgment of March 2, 2009.

${ }^{104}$ ISLAM, National Trials of International Crimes in Bangladesh 191.

105 ISLAM, National Trials of International Crimes in Bangladesh 191.

106 ISLAM, National Trials of International Crimes in Bangladesh 191; EATON, Sierra Leona 908; NowROJEE, Making the Invisible War Crime Visible 85-105; MudDELL, Capturing Women’s Experience of Conflict 85-100.
} 


\subsection{International Crimes Tribunal, Bangladesh (ICT-BD)}

Rape is a component of crime against humanity under section 3(2)(a) and its perpetrators incur individual and joint criminal responsibility under section 4 of the International Crimes (Tribunals) Act, 1973. ${ }^{107}$ As mentioned by Prof. Islam, the ICT-BD judgments interpreted 'rape' broadly to encompass all forms of sexual abuses including abduction, violence, assault, slavery, forced pregnancy, enforced prostitution, confinement, torture, persecution, and similar other inhumane acts. ${ }^{108}$

While dealing with the culpability of wartime rape and criminal liability of the perpetrators, in the case of Mobibur and others, the tribunal observed that "... [Rape] is a beastly act of robbery that takes away the thing that cannot be given back. Mass rape if graver than murder. The event of committing rape by Pakistani army men on the victims, as evidenced, once against proves that the Pakistani occupation army had carried out such monstrous activities intending not to put grave wound to the victims only, but to provide a message of intimidation to the pro-liberation civilians and the society. The perpetrators were thus a synonym of 'beast' indeed and the accused persons were their active aiders and abettors who as well incur liabilities..."109 In this case, joint criminal enterprise became an issue and three accused were held liable for crime against humanity for committing the crime jointly, thus being equally responsible. ${ }^{110}$

In the case of Sayeedi, the ICT-1 found that the alleged himself did not commit the offence directly by substantially facilitate the commission of rape by other, and on that ground for abduction and confinement of women for committing rape constituted crime against humanity. ${ }^{111}$ Similarly, in Nizami case, the ICT-1 considered the charged of complicity and contribution to rape and persecution as crimes against humanity and found the accused guilty. ${ }^{112}$

The tribunal characterized 'genocidal rape' as more than murder because of its infliction of grievous bodily harms on the victims with life-long psychological and mental trauma. ${ }^{113}$ This approach tends to enrich the existing international criminal jurisprudence on wartime rape and sexual violence but has the potential of raising the issue of applying the post-facto judicial precedents retrospectively.

\section{Concluding Remarks}

"Conflict-related sexual violence is not specific to any cultural or continent, $[. .$.$] it is neither cultural nor even sexual-$ but criminal, a crime of international concern."14 This paper tried to analyze the historical development of wartime sexual acts as prosecutable war crimes, and how the International Crimes Tribunals/Courts articulated the extent of criminality and culpability of wartime rapes and other sexual violence and their nexus with crimes against humanity, genocide, and war crimes, within the corpus of international

\footnotetext{
107 Akayesu Case, note 94, 191.

108 Akayesu Case, note 94, 191.

109 Chief Prosecutor v Mohibur and others, ICT-1 Judgment, para 383, 225-226, 283, 331, 342, 381, 384-390.

${ }_{110}$ Chief Prosecutor v Mohibur and others, ICT-1 Judgment, para 390.

111 Sayeedi Judgment, para 205.

112 Nizami Judgment, para 419.

113 Moslem and Hossain Judgment, para. 390-394, 397, 404, 408, 335.

114 WALlSTRÖM, (previous) Special Representative of the Secretary-General on Sexual Violence in Conflict (SRSG).
} 
norms and criminal prohibitions. From the ancient time till the 90s century, sexual atrocities were considered as an unfortunate but inevitable byproduct of war, but in fact, it is a crime, strategically planned by the armed forces to control the occupied territories. Manenti rightly said that these sexual atrocities were a "tool of intimidation and social control". ${ }^{115}$ In the patriarchal societies where the status of women is often conceived in relation to marriage and motherhood, because of the consequences of rape, including stigma and infertility, may exclude victims from the community life, e.g. Biranganas' in Bangladesh [women who were raped during the Bangladesh Liberation War, 1971]. ${ }^{116}$

However, after the 1990s, "we have witnessed the increasing attention of the international community on conflict related sexual abuses. ${ }^{117}$ We have observed how the United Nations showed their great concern for the protection of violence against women and thus, organized four world conferences on women and the UN Security Council unanimously adopted Resolution 1820 (2008) acknowledging sexual violence as a "tactic of war" challenging international peace and security. ${ }^{118}$ We have seen how the international tribunals/courts are recognizing the sexual atrocities into their concern and how they are adjudicating all the matters in just and prompt manner.

In this modern era, the wartime rape and sexual violence/atrocities are universally recognized as the constituent elements of crimes against humanity, war crimes, and genocide. ${ }^{119}$ Special thanks to the ad hoc tribunals, because it is their achievements to recognize these forms of sexual violence as criminal acts and can be amount to war crimes, genocide, crimes against humanity. ${ }^{120}$ It is important to note that the special tribunals and courts have been proactively engaged in changing the world's perception of rape and sexual violence in armed conflicts and its longstanding stereotype legal status through their groundbreaking judgments. ${ }^{121}$ Their contributions are widely regarded as authoritative and a legitimate advancement of international criminal law to confront gender-based crimes far beyond the Nuremberg approach by protecting the victims and punishing the perpetrators.

\section{Bibliography}

Boling, David: Mass Rape, Enforced Prostitution, and the Japanese Imperial Army: Japan Eschews International Legal Responsibility?. Columbia Journal of Transitional Law 32, 3/1995

Brownmiller, Susan: Against Our Will, Men, Women and Rape. New York 1975

115 UN Secretary-General (UNSG) Report on Sexual Violence in Conflict, 13 March 2014, S/2014/181.

116 WOOD, Armed Groups and Sexual Violence 216; WALLSTRÖM, (previous) SRSG, Statement, Publication launch.

117 WOOD, Armed Groups and Sexual Violence 217.

118 WoOD, Armed Groups and Sexual Violence, para 3.

119 Prosecutor v Alfred Musema, ICTR-96-13-T, trial judgment and sentence of January 27, 208.

120 WoOD, Armed Groups and Sexual Violence 217; Consider, in particular, that the ICC Statute is the first international instrument expressly including various forms of sexual and gender-based crimes (rape, sexual slavery, enforced prostitution, forced pregnancy, enforced sterilization and other forms of sexual violence) as underlying acts of both crimes against humanity and war crimes committed in international and non-international armed conflicts. The Statute also criminalizes persecution based on gender as a crime against humanity. Sexual and gender-based crimes may also fall under the Court's jurisdiction if they constitute acts of genocide or other acts of crimes against humanity or war crimes. (ICC Office of the Prosecutor, Policy Paper on Sexual and Gender-Based Crimes, June 2014.

121 WoOD, Armed Groups and Sexual Violence, para 2. 
COPELON, Rhonda: General Crimes as War Crimes: Integrating Crimes against Women into International Criminal Law. McGill Law Journal 46, 1/2000

FrITZ, Nicole - SMITH, Alison: Current Apathy for Coming Anarchy: Building the Special Court for Sierra Leone. Fordham International Law Journal 25, 2/2001

Greenberg, Karen - Dratel, Joshua (eds.): The Torture Papers: The Road to Abus Ghraib. Cambridge 2005

Grotius, Hugo: De Iure Belli ac Pacis Libri Tres II (On the Laws of War and Peace II). KeLSEY, Francis W. (trans.), Clark 1995

HERBERMANN, Nanda: The Blessed Abyss: Inmate \#6582. In: Ravensbruck Concentration Camp for Women. Cambridge 2000

Hersh, Seymour: Torture at Abu Ghraib. The New Yorker, May 10, 2004, $42-44$.

HiCKS, George: Ghosts Gathering: Comfort Women Issue Haunts Tokyo as Pressure Mounts. Far Eastern Economic Review 157, 7/1993

ISLAM, M. Rafiqul: National Trials of International Crimes in Bangladesh: Transitional Justice as Reflected in Judgments. Dhaka 2019

MANENTI, Martina Roberta: Wartime Sexual Violence as an International Crime. PhD Dissertation. Milano 2015

MCCORMACK, Tim: Selective Reaction to Atrocity: War Crimes and the Development of International Criminal Law. Albany Law Review 60, 3/1997

MENON, Theodor: Rape as a Crime under International Humanitarian Law. American Journal of International Law 87, $3 / 1993$

MENON, Theodor: Shakespeare's Henry the Fifth and the Law of War, American Journal of International Law, 86, I/1982

MoOKHERJEe, Nayanika: Mass Rape and the Inscription of Gendered and Racial Discrimination During the Bangladesh War of 1971. In: BRANCHE, Raphaelle - VIRGILE, Fabrice (eds.): Rape in Wartime. Palgrave Macmillan 2012

MudDELL, Kelli: Capturing Women's Experience of Conflict: Transitional Justice in Sierra Leone. Michigan State Journal of International Law 15, 1/2007

NiARCHOS, Catherine: Women, War and Rape: Challenges Facing the International Tribunal for the Formal Yugoslavia. Human Rights Quarterly 17, 4/1995

NowrojEe, Binaifer: Making the Invisible War Crime Visible: Post Conflict Justice for Sierra Leone's Rape Victims. Harvard Human Rights Journal 18/2005

PARKER, Karen - CHEW, Jennifer: Compensation for Japan's World War II Victims. Hastings Journal of International and Comparative Law 17, 3/1994

RAY, Amy: The Shame of It: Gender-based Terrorism in the Former Yugoslavia and the Failure of International Human Rights Law to Comprehend the Injuries. American University Law Review 46, 3/1997

SAIKIA, Yasmin: Beyond the Archive of Silence: Narrative of Violence of the 1971 Liberation War of Bangladesh. History Workshop Journal 58, 1/2004

SELLERS, Patricia: Individual('s) Liability for Collective Sexual Violence. In: KNOP, Karen (ed.): Gender and Human Rights. Oxford 2004

SELLERS, Patricia - OKIZUMI, Kaoru: International Prosecution of Sexual Violence. Transitional Law \& Contemporary Problems 7/1997

The Nuremberg Judgment 1946 reproduced in American Journal of International Law 41, 1/1947

YU, Tong: Reparations for Former Comfort Women of World War II. Harvard International Law Journal 36, 2/1995

\section{Reports}

Application in of the Convention on the Prevention and Punishment of the Crime of Genocide (Bosnia-Herzegovina v Yugoslavia (Serbia and Montenegro)), [1993] ICJ Report 3 at 24, Provisional Measures, Order of April 8, 1993, para $52 \mathrm{~A}(2), 24$. 
BBC News Online, Surprise at Sierra Leone Arrests (accessed on September 10, 2020) http:// news.bbc.co.uk/1/hi/world/africa/2839491.stm.

EAton, S.: Sierra Leona: The Proving Ground for Prosecuting Rape as a War Crime. Georgetown Journal of International Law 35, 4/2004

Final Report of the Commission of Experts on Rwanda, UN Doc. S/1994/1405 (1994), Annex. Gendercide watch, Case Study: Bosnia-Herzegovina, http://www.gendercide.org/case_bosnia.html

ICC Office of the Prosecutor, Policy Paper on Sexual and Gender-Based Crimes, June 2014 http://www.icc-cpi.int/iccdocs/otp/OTP-Policy-Paper-onSexual-and-Gender-Based Crimes--June-2014.pdf (accessed on September 10, 2020)

ICRC Update on the Aide-memoire, December 3, 1992; DURHAM, Helen - GuRD, Tracey (eds.): Listening to the Silences: Women and War. Leiden - Boston 2005

Photographs of sexualized abuses in the Abu Ghraib prison and around Iraq are well documented and publicized: FISHER, Ian: Iraqi Tells of US Abuse, from Ridicule to Rape. New York Times, May 14, 2004, 8

Report on the Mission to the Democratic People's Republic of Korea, the Republic of Korea and Japan on the Issue of Military Sexual Slavery in Wartime submitted to the UN Human Rights Commission by IN Special Rapporteur Radhika Coomaraswamy, February 5, 1996, UN Docs. E/CN.4/1996/53/Add.1.

Report on the Situation of Human Rights in Rwanda to the Commission on Human Rights, UN Docs. E/CN.4/1996/68, 1996

TAYLOR, Louise: We'll Kill You if You Cry: Sexual Violence in Sierra Leone Conflict. Human Rights Watch 15, 1/2003 10-25 (accessed on September 10, 2020) https://www.hrw.org/reports/2003/sierraleone/sierleon0103.pdf

The European Community investigative mission into the treatment of Muslim women in the former Yugoslavia: Report to EC Foreign Ministers, UN Doc. S/25240, Annex I/1993

UN General Assembly Res. 3318, UN Doc. A/9631, 1974

UN Secretary-General (UNSG) Report on Sexual Violence in Conflict, 13 March 2014, S/2014/181

WALlSTRÖM, Margot: (previous) SRSG, Statement, Publication launch: Addressing Conflict-Related Sexual Violence: An Analytical Inventory of Peacekeeping Practice”, New York, 30 June 2010 (accessed on September 10, 2020) http://www.stoprapenow.org/uploads/advocacyresources/1282163226.pdf

WALLSTRÖM, Margot: (previous) Special Representative of the Secretary-General on Sexual Violence in Conflict (SRSG), Statement to the Security Council, 14 October 2010 (accessed on September 10, 2020) http://www.stoprapenow.org/uploads/images/features/pdf/21_oct_SRSG_SVC_Statement to Council on DRC1.pdf

WooD, Elisabeth Jean: Armed Groups and Sexual Violence, supra at 24: On the Issue of Wartime 'Comfort Women', by the Japanese Cabinet Councilors’ Office on External Affairs, August 4, 1993 E/CN.4/1996/137 